\title{
Winter rainfall predicts phenology in widely separated populations of a migrant songbird
}

\author{
Ann E. McKellar - Peter P. Marra • Susan J. Hannon • \\ Colin E. Studds $\cdot$ Laurene M. Ratcliffe
}

Received: 1 November 2011/Accepted: 17 October 2012/Published online: 17 November 2012

(C) Springer-Verlag Berlin Heidelberg 2012

\begin{abstract}
Climate change is affecting behaviour and phenology in many animals. In migratory birds, weather patterns both at breeding and at non-breeding sites can influence the timing of spring migration and breeding. However, variation in responses to weather across a species range has rarely been studied, particularly among populations that may winter in different locations. We used prior knowledge of migratory connectivity to test the influence of weather from predicted non-breeding sites on bird phenology in two breeding populations of a long-distance migratory bird species separated by $3,000 \mathrm{~km}$. We found that winter rainfall showed similar associations with arrival and egg-laying dates in separate breeding populations on
\end{abstract}

Communicated by Ola Olsson.

A. E. McKellar $(\bowtie) \cdot$ L. M. Ratcliffe

Department of Biology, Queen's University,

Kingston, ON K7L 3N6, Canada

e-mail: mckellara@missouri.edu

Present Address:

A. E. McKellar

Department of Fisheries and Wildlife Sciences,

University of Missouri, Columbia, MO 65211, USA

P. P. Marra - C. E. Studds

Smithsonian Conservation Biology Institute,

Migratory Bird Center, National Zoological Park,

Washington, DC 20008, USA

S. J. Hannon

Department of Biological Sciences, University of Alberta,

Edmonton, AB T6G 2E9, Canada

Present Address:

C. E. Studds

School of Biological Sciences, University of Queensland,

Brisbane, QLD 4072, Australia an east-west axis: greater rainfall in Jamaica and eastern Mexico was generally associated with advanced American redstart (Setophaga ruticilla) phenology in Ontario and Alberta, respectively. In Ontario, these patterns of response could largely be explained by changes in the behaviour of individual birds, i.e., phenotypic plasticity. By explicitly incorporating migratory connectivity into responses to climate, our data suggest that widely separated breeding populations can show independent and geographically specific associations with changing weather conditions. The tendency of individuals to delay migration and breeding following dry winters could result in population declines due to predicted drying trends in tropical areas and the tight linkage between early arrival/breeding and reproductive success in long-distance migrants.

Keywords American redstart - Climate change .

Migration · Migratory connectivity $\cdot$ Setophaga ruticilla

\section{Introduction}

Animal phenologies are changing along with recent climate change (Root et al. 2003). Many bird species show earlier spring arrival and egg-laying dates in response to warmer spring temperatures (Both et al. 2004; Lehikoinen and Sparks 2010), and higher winter rainfall or temperatures have been correlated with earlier departure from the nonbreeding grounds and earlier arrival to the breeding grounds in some migratory birds (Saino et al. 2004, 2007; Gordo et al. 2005; Studds and Marra 2011). However, variation in such responses among migratory populations across breeding and non-breeding ranges has received less attention (but see Both et al. 2006; Balbontín et al. 2009a; Wilson et al. 2011). Understanding how weather from one 
phase can carry over to influence migratory animals during subsequent phases of their annual cycle is becoming increasingly important in light of global climate change. This is especially critical when considering the tight linkage between arrival timing to the breeding grounds and reproductive success (e.g., Møller 1994; Lozano et al. 1996). Our study focuses on the potential influence of rainfall from the non-breeding grounds on the phenology of widely separated breeding populations of the American redstart (Setophaga ruticilla), a long-distance NeotropicalNearctic migratory warbler.

Migratory birds might respond to a changing climate through two non-exclusive mechanisms: population- or individual-level adjustment. Population-level change could arise because of dispersal of new individuals into the population, for example, the shifting ranges of some northern hemisphere birds (Thomas and Lennon 1999; Hitch and Leberg 2007). Such shifts could bring earlierlaying individuals farther north and result in changes in mean population laying dates. Population-level change might also occur through changes in gene frequencies via selection. For example, deteriorating conditions at a stopover site are thought to have caused selection against poorquality male barn swallows (Hirundo rustica), resulting in a rapid increase in mean tail length in a breeding population (Møller and Szép 2005). Overall, strong evidence for microevolution in response to recent climate change is lacking, perhaps in part because it is difficult to detect (Gienapp et al. 2008). Individual-level adjustment to climate via phenotypic plasticity, on the other hand, has been documented in several longitudinal studies where marked birds have been followed in different climatic conditions over at least 2 years (Saino et al. 2004; Gunnarsson et al. 2006; Balbontín et al. 2009b; Studds and Marra 2011). In most cases, the extent of phenotypic plasticity detected has been sufficient to explain population changes in response to climate. However, the majority of these studies have focused on European migrants, and comparable studies of North American species are lacking.

Migratory connectivity (the extent to which individuals from the same non-breeding area migrate to the same breeding area and vice versa; Marra et al. 2010) may affect how breeding populations will respond to variation in nonbreeding weather conditions. In less-connected populations, the influence of weather at a particular non-breeding location might not be as apparent because individuals from such a location would disperse to multiple breeding sites (Marra et al. 2010). Low levels of connectivity could thus buffer local populations against declines owing to habitat loss or degradation that occur during one part of their annual cycle (e.g., Jones et al. 2008). In more-connected populations, the influence of non-breeding conditions on migration might be stronger and easier to detect, and spatial variation in non-breeding weather could result in corresponding variation in response across the breeding range.

American redstarts are thought to exhibit reasonably strong migratory connectivity, as evidenced by a handful of recoveries of banded birds and stable-hydrogen isotope analysis of feathers moulted on the breeding grounds and sampled across the non-breeding range (Norris et al. 2006; C.E. Studds and P.P. Marra, unpublished data). Across 26 sampling locations spanning the non-breeding range of redstarts, feather hydrogen isotopic values were strongly correlated with longitude of the sampling location, which suggests that redstarts show east-west clinal variation in their migration. Furthermore, assignment tests indicated that eastern non-breeding populations were more likely to breed in eastern and southern breeding locations, and western non-breeding populations were more likely to breed in northwestern breeding locations (Norris et al. 2006). Thus, we might expect longitudinally separated breeding populations to respond to variation in winter rainfall from non-breeding areas along a corresponding east-west axis (see also Wilson et al. 2011). In addition, given strong levels of migratory connectivity across longitude, one would predict that migratory timing (e.g., departure dates from the non-breeding grounds and arrival dates to the breeding grounds) should be correlated between particular breeding and non-breeding regions along this axis.

Assessing how species respond to variation in weather, if this response differs among populations across their range, and the mechanism responsible for this response (i.e., microevolution and/or plasticity) are fundamental to understanding how continued climate change will affect migratory species. In this study, we investigate variation in arrival and laying dates over 10 years in two breeding populations of American redstarts. These sites, in eastern Ontario and central Alberta, Canada, are located at opposite sides of the breeding range of redstarts approximately $3,000 \mathrm{~km}$ apart (Fig. 1). We determine whether rainfall at different non-breeding locations, each assumed to correspond to a particular breeding population, is associated with arrival and laying dates. For one breeding population with sufficient data, we also evaluate whether the above associations could be due to plasticity alone by examining within-individual changes in phenology in relation to interannual changes in non-breeding rainfall (Charmantier et al. 2008). We predicted that (1) increased winter rainfall in Jamaica would be associated with earlier arrival and laying dates in Ontario, whereas increased winter rainfall in Mexico would be associated with earlier arrival and laying dates in Alberta, and that (2) these associations could be explained by changes in individual behaviour. Finally, we provide a preliminary analysis from a smaller 6-year 


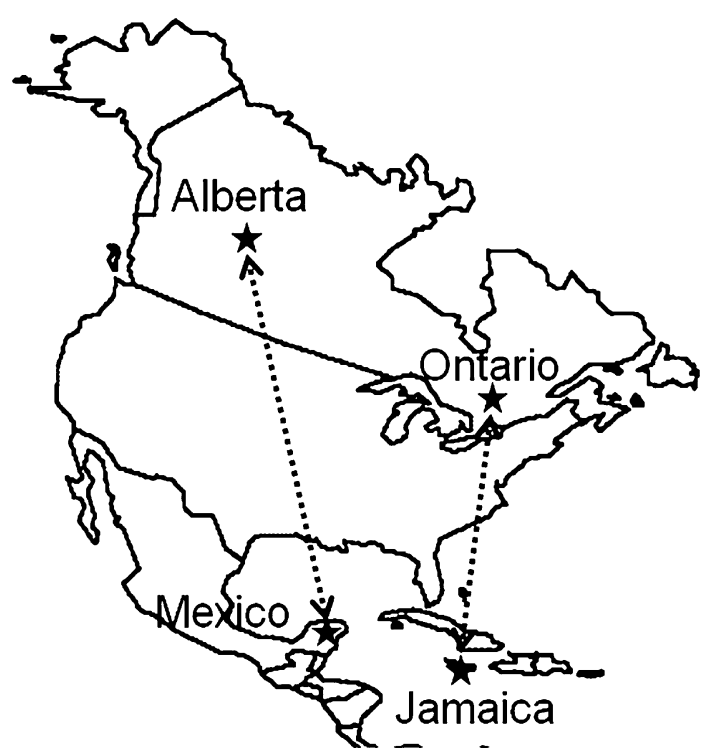

Fig. 1 Study locations and predicted migratory connectivity in American redstarts (Setophaga ruticilla). Breeding populations were studied in Ontario and Alberta, Canada. A non-breeding population was studied in Westmoreland, Jamaica, and rainfall data were collected for Jamaica and eastern Mexico. Dashed lines connect nonbreeding populations to their most likely breeding region, as inferred from stable isotope analysis (see text; Norris et al. 2006)

dataset of departure dates from a Jamaican non-breeding population to test their potential association with arrival and laying dates in Ontario.

\section{Materials and methods}

\section{Field data}

American redstarts are sexually dimorphic, and males exhibit delayed plumage maturation. Males in their first breeding season resemble females and do not mature into their full adult breeding plumage until their second prebasic moult, following their first breeding season. Adult (aftersecond-year or ASY) males arrive first to the breeding grounds, and are followed approximately 1 week later by young males (second-year or SY) and females (Sherry and Holmes 1997). Early male arrival is strongly associated with increased reproductive success in this species (Lozano et al. 1996; Smith and Moore 2005; Reudink et al. 2009). We focused on ASY male arrivals because SY males often move around before settling, annual numbers of SY males varied substantially in our study populations, and SY male migratory timing is influenced by factors in addition to weather (e.g., social competition affecting departure dates from the non-breeding grounds; Studds et al. 2008). For females, we used first egg date as a proxy for arrival because females are often inconspicuous on arrival, making arrival dates less accurate. Since females pair upon arrival by selecting among already-established males (Ficken 1963), the date of initiation of their first breeding attempt should be strongly related to their true arrival date to the breeding grounds (Smith and Moore 2005). Furthermore, though female arrivals were not estimated in Alberta, annual mean first egg dates in Ontario were strongly correlated with estimates of female arrival based on first sightings of females (2001-2010: $\left.r^{2}=0.51, t_{8}=2.89, P=0.02\right)$. We included both ASY and SY females in our analyses to ensure sufficient sample sizes (females are more difficult to capture than males, they must be captured to be aged, and even so, ageing females can be ambiguous; Pyle 1997), and we detected no difference in first egg dates between knownage ASY and SY females (A.E. McKellar, unpublished data).

Field work in eastern Ontario was conducted from 2001 to 2010 on a 100 -ha site at the Queen's University Biological Station $\left(44^{\circ} 34^{\prime} \mathrm{N}, 76^{\circ} 19^{\prime} \mathrm{W}\right)$. This study site is composed of mixed-deciduous forest, primarily dominated by sugar maple (Acer saccharum) and eastern hophornbeam (Ostrya virginiana). From 1 to 31 May each year, we monitored this site from 0600 to 1200 hours every day to detect the presence of American redstart males by listening for singing and subsequent visual identification. We identified males that were not already banded from a previous year by the size and shape of the distinctive black bib on their breast until they could be captured. We recorded the first day that a new male was identified as his arrival date. This method for estimating male arrival date has proven effective in revealing differences in reproductive success and in non-breeding habitat occupancy through the use of stable isotopes (Reudink et al. 2009). We mapped the positions of males for at least $20-30 \mathrm{~min} /$ day to determine territory boundaries and pairing. Once males were paired to females, we monitored territories each day until we located nests and determined first egg dates of first nesting attempts. We captured males in mist nets upon their arrival by simulating a territorial intrusion with the use of a stuffed male decoy and song playback. We captured females in a similar fashion or with the use of fledgling distress playback during nestling or fledgling feeding. We banded males and females with a unique combination of colour bands and a single Canadian Wildlife Service aluminum band.

Field work in central Alberta was conducted from 1995 to 2005 (excluding 1997) on a 2,722-ha site in and around the Meanook Biological Research Station $\left(54^{\circ} 37^{\prime} \mathrm{N}\right.$, $\left.113^{\circ} 20^{\prime} \mathrm{W}\right)$. This study site is composed of forest fragments containing aspen (Populus tremuloides), balsam poplar (Populus balsamifera), and conifers (white spruce Picea glauca, black spruce Picea mariana, and tamarack larch Larix laricina), interspersed within a landscape of agricultural fields, livestock grazing areas, farmyards, and 
roads. Within forest fragments, redstarts bred in clusters of wet, dense, and structurally heterogeneous stands of willow (Salix spp.) and alder (Alnus spp.). Field work was performed similarly, but differences in study objectives between our two breeding locations meant that recordings of arrival dates were done only from 2002 onwards, and individuals were banded only from 2000 onwards.

Field work in Jamaica was conducted from 2003 to 2009 (excluding 2006) on five 5-ha study plots at the Font Hill Nature Preserve $\left(18^{\circ} 02^{\prime} \mathrm{N}, 77^{\circ} 57^{\prime} \mathrm{W}\right.$ ) (see also Studds and Marra 2011). Study plots were either wetter mangrove stands (three study plots) dominated by black mangrove (Avicennia germinans) with some white (Laguncularia racemosa) and red mangrove (Rhizophora mangle), or drier second-growth stands (two study plots) dominated by invasive logwood trees (Haematoxylon campechianum) with some other species including Bursera simaruba, Terminalia latifolia, and Crescentia alata. We pooled departure dates from both habitat types, but results were similar if we restricted our analysis to one or the other habitat type. From 15 January to 15 April each year, we captured American redstarts as above as well as with passive mist netting. We banded individuals with a unique combination of colour bands and a single United States Geological Survey aluminum band. We followed individuals for a minimum of $3 \mathrm{~h}$ each to map their territories. From 1 April to 15 May, we searched territories every 3 days to estimate the date redstarts left for spring migration. When we failed to re-sight a bird, we checked the territory twice more during the next 3-day period and once more during the following 3-day period. On the final visit, we broadcast playback of redstart songs and chips. If playback drew no response, we considered birds to have departed during the initial 3-day period when we first failed to detect them. As above, we restricted our analyses to ASY male departures but included both ASY and SY female departures.

\section{Weather data}

We obtained non-breeding season rainfall data for Jamaica and eastern Mexico (Fig. 1). Based on banded recoveries and stable isotope data, we made the assumption that the greatest proportion of American redstarts from Jamaica and eastern Mexico, in comparison to other non-breeding locations, should breed in the northeastern (including Ontario) and northwestern (including central Alberta) parts of their breeding range, respectively (see Norris et al. 2006: fig. 3). We used mean rainfall from January to March as a measure of dry season rainfall. Although a recent study at the same non-breeding site in Jamaica found rainfall in March only to be the strongest predictor of individual departure dates (Studds and Marra 2011), we here used January to March rainfall because it is also associated with American redstart food availability, body condition, and departure date from the non-breeding grounds (see "Results"; Studds and Marra 2007; Angelier et al. 2011). Also, March rainfall in Mexico was zero for several years used in our analysis, whereas rainfall in January and February was higher and more variable and thus allowed for annual variation in January to March rainfall across years. Jamaica rainfall data (1995-2010) were provided for Burnt Savannah, Westmoreland, Jamaica $\left(18^{\circ} 19^{\prime} \mathrm{N}, 78^{\circ} 5^{\prime} \mathrm{W}\right)$ by the Jamaica Meteorological Service (http://www.metservice.gov.jm), and Mexico rainfall data (1995-2010) were averaged for five weather stations on the Yucatán peninsula (ranging from $19^{\circ} 34^{\prime}$ to $21^{\circ} 18^{\prime} \mathrm{N}$ and $88^{\circ} 1^{\prime}$ to $90^{\circ} 32^{\prime} \mathrm{W}$ ) from the National Oceanic and Atmospheric Administration's (NOAA) Climate Prediction Centre, available from the IRI/ LDEO Climate Data Library (http://iridl.ldeo.columbia.edu/).

We obtained local breeding season temperature data for Ontario from a weather station at the Queen's University Biological Station. Local temperature data for Alberta were provided by Environment Canada's National Climate Data and Information Archive (http://climate.weatheroffice. gc.ca/) from a weather station in Edmonton, Alberta, $120 \mathrm{~km}$ south of the Meanook Biological Research Station. We averaged daily temperature means for the arrival or laying period across all years at each site, although results were similar if we used local breeding season temperature for 1 or 2 weeks preceding the annual mean arrival or first egg dates. Local temperature during similar time periods has been shown to predict phenology and abundance in certain migratory populations (Dunn and Winkler 1999; Marra et al. 2005; Smith et al. 2009; Wilson et al. 2011). Although temperatures en route can also be associated with migratory timing (Marra et al. 2005), our goal here was to assess whether rainfall from predicted non-breeding locations was associated with redstart phenology, rather than to discover all sources of variation in timing of arrival and egg-laying. Thus, rather than reducing power by incorporating additional weather variables in our models, we restricted our analyses to include winter rainfall and local breeding season temperature, which represent breeding season conditions and should also correlate with nearby conditions en route (e.g., Tøttrup et al. 2010).

Statistical analyses

We performed statistical analyses in $\mathrm{R}$ version 2.14.2 (R Development Core Team 2011). To determine whether Ontario and Alberta breeding populations differed in their responses to rainfall at the two non-breeding areas, we constructed two Generalized Linear Mixed Models (GLMM) using the R package 'Ime4' (Bates et al. 2011). We modelled male arrival date or female first egg date as a 
function of rainfall in Jamaica, rainfall in Mexico, breeding location (Ontario or Alberta), and both two-way interactions between breeding location and rainfall (i.e., 'breeding location' $x$ 'Jamaica rainfall' and 'breeding location' $x$ 'Mexico rainfall'). Both models included individual and year as random effects. We evaluated the significance of interactions via likelihood ratio tests by removing each interaction in turn and comparing the difference in deviance between the resultant model and the full model. These differences in deviance approximately follow a Chi-square distribution with one degree of freedom (Zuur et al. 2009). Significant interaction terms (see "Results") indicated that associations between winter rainfall and response variables at each breeding population indeed differed between the breeding populations.

We thus proceeded to model male arrival date and female first egg date for Ontario and Alberta separately, with rainfall from the corresponding predicted nonbreeding area. This new set of four GLMMs included rainfall from the predicted wintering area and local breeding season temperature as fixed effects, and individual and year as random effects. We evaluated the significance of fixed effects with likelihood ratio tests as above. To evaluate the direction of the association between response variables and effects, we present effect estimates and standard errors from final models including only significant effects. We used Gaussian distributions and identity link functions for all GLMMs.

To examine whether phenotypic plasticity could explain results from the above models, we first determined the slope of the relationship between mean within-individual changes in arrival or first egg dates and interannual changes in rainfall for banded individuals that returned in consecutive years. We compared these estimates to the slope of the relationship between mean annual arrival or first egg dates and rainfall. Similar slopes would indicate that population-level changes could be explained by changes in individual behaviour (see also Charmantier et al. 2008; Matthysen et al. 2011). These analyses were only performed for the Ontario breeding site due to the smaller number of years for which individuals were banded in Alberta and the consequently small number of years with returning individuals.

To examine associations between departure in Jamaica and arrival to the breeding grounds, we performed correlation analyses between adult male departure from Jamaica and arrival in Ontario, and female departure from Jamaica and first egg date in Ontario. We only performed these analyses for the Ontario breeding site because (1) there were only 3 years of overlap between Alberta and Jamaica datasets, and (2) we detected significant associations between Jamaica rainfall and redstart phenology in Ontario (see "Results"). Due to the small number of years $(n=6)$ in this exploratory analysis and because both arrival/egglaying and departure dates were associated with measurement error, we present non-parametric correlations.

\section{Results}

Weather and spring arrival and laying dates

We did not detect any strong multicollinearity that would have affected our results, as indicated by non-significant correlations and small variance inflation factors (VIF). Correlation coefficients for variables used in the same models were all $<0.51$ and non-significant (Table 1 ; values $>0.8$ indicate possible multicollinearity; Glantz and Slinker 2001), and VIFs were $<2.4$ (VIF $>10$ represents evidence of significant multicollinearity, and $\mathrm{VIF}>4$ represents moderate multicollinearity; Glantz and Slinker 2001).

We obtained arrival dates for 373 adult male American redstarts in Ontario and 97 in Alberta, and first egg dates for 251 female American redstarts in Ontario and 456 in Alberta. Breeding locations generally differed in their associations with rainfall from each non-breeding location. Specifically, arrival dates differed between breeding locations in response to rainfall in Jamaica ('breeding location' $\times$ 'Jamaica rainfall' interaction: $\chi_{1}^{2}=7.86, P=$ $0.005, n=470$ ) and in Mexico ('breeding location' $\times$ 'Mexico rainfall' interaction: $\chi_{1}^{2}=29.9, P<0.001, n=$ 470), and first egg dates differed between breeding locations in response to rainfall in Jamaica $\left(\chi_{1}^{2}=15.77, P<\right.$ $0.001, n=707)$, but not in Mexico $\left(\chi_{1}^{2}=1.95, P=0.162\right.$, $n=707)$.

Mixed models containing all individuals revealed that adult males in Ontario arrived significantly earlier and females in Ontario had significantly earlier first egg dates when rainfall in Jamaica was higher (Table 2; Fig. 2). Local breeding season temperature in Ontario was not related to arrival or first egg dates in Ontario. Females in Alberta had significantly earlier first egg dates when rainfall in Mexico was higher, but adult male arrival dates in Alberta were not related to rainfall in Mexico (Table 2; Fig. 3). Local breeding season temperature in Alberta was not related to arrival or first egg dates in Alberta.

The slope of the relationship between within-individual changes in arrival dates of adult males in Ontario and interannual changes in rainfall in Jamaica $(-0.045 \pm$ 0.021 days $\mathrm{mm}^{-1}$ ) was very similar to that between mean arrival date and rainfall in Jamaica at the population level $\left(-0.043 \pm 0.018\right.$ days $\mathrm{mm}^{-1}$; Fig. 2$)$. The slope of the relationship between within-individual changes in female first egg dates in Ontario $\left(-0.083 \pm 0.053\right.$ days $\left.\mathrm{mm}^{-1}\right)$ was also similar to that at the population level 
Table 1 Correlation coefficients among weather variables at two non-breeding and two breeding areas of American redstarts (Setophaga ruticilla)

\begin{tabular}{lrllll}
\hline & Jam rain & Mex rain & ON arr temp & ON egg temp & AB arr temp \\
\hline Mex rain & $0.38(15)$ & - & - & - & - \\
ON arr temp & $-0.17(10)$ & $0.18(10)$ & - & - & - \\
ON egg temp & $-0.46(10)$ & $0.28(10)$ & $0.80 *(10)$ & - & - \\
AB arr temp & $0.03(10)$ & $0.51(10)$ & $-0.61(5)$ & $-0.23(5)$ & - \\
AB egg temp & $0.06(10)$ & $0.46(10)$ & $-0.63(5)$ & $-0.26(5)$ & $0.94 *(10)$ \\
\hline
\end{tabular}

Sample sizes are shown in parentheses and indicate the number of years of overlap for those variables

Jam rain Jamaica rainfall $(\mathrm{mm})$, Mex rain Mexico rainfall $(\mathrm{mm})$, ON arr temp mean temperature $\left({ }^{\circ} \mathrm{C}\right)$ during arrival in Ontario, ON egg temp mean temperature $\left({ }^{\circ} \mathrm{C}\right)$ during first egg-laying period in Ontario, $A B$ arr temp mean temperature $\left({ }^{\circ} \mathrm{C}\right)$ during arrival in Alberta, $A B$ egg temp mean temperature $\left({ }^{\circ} \mathrm{C}\right)$ during first egg-laying period in Alberta

* Significant at $P<0.05$

Table 2 Results of GLMMs explaining variation in adult male arrival and female first egg dates at two breeding populations of American redstarts

\begin{tabular}{llll}
\hline & $\chi_{1}^{2}$ & $P$ & Estimate $\pm \mathrm{SE}$ \\
\hline Ontario arrival model & $n=373$ & & \\
Jam rain & 4.54 & 0.033 & $-0.041 \pm 0.018$ \\
ON arr temp & 0 & 1 & - \\
Ontario first egg model & $n=251$ & & \\
Jam rain & 11.85 & $<0.001$ & $-0.059 \pm 0.017$ \\
ON egg temp & 2.66 & 0.103 & - \\
Alberta arrival model & $n=97$ & & \\
Mex rain & 0.40 & 0.525 & - \\
AB arr temp & 0 & 1 & - \\
Alberta first egg model & $n=456$ & & \\
Mex rain & 5.36 & 0.021 & $-0.083 \pm 0.033$ \\
AB egg temp & 0 & 1 & -
\end{tabular}

Individual and year were included as random effects. Significance of fixed effects (see Table 1 for abbreviations and units) was evaluated via likelihood ratio tests by removing each sequentially from a full model containing all fixed effects. Estimates from final models containing only significant fixed effects are shown

$\left(-0.063 \pm 0.015\right.$ days $\mathrm{mm}^{-1}$; Fig. 2$)$, though the standard error for within-individual changes was large due to the smaller number of years with multiple returning females $(n=5)$. The above results indicate that the populationlevel responses in Ontario to rainfall in Jamaica can likely be explained by phenotypic plasticity.

Winter departure dates and spring arrival dates

Mean arrival and first egg dates tended to be earlier in years when males and females departed earlier from Jamaica, but non-parametric correlations were non-significant (arrival: Spearman's $r=0.37, P=0.479$; first egg: Spearman's $r=0.60, P=0.208$; Fig. 4). Mean male departure from Jamaica was earlier in years when rainfall in Jamaica was higher $\left(r^{2}=0.80, t_{4}=-3.98, P=0.017\right)$, but this

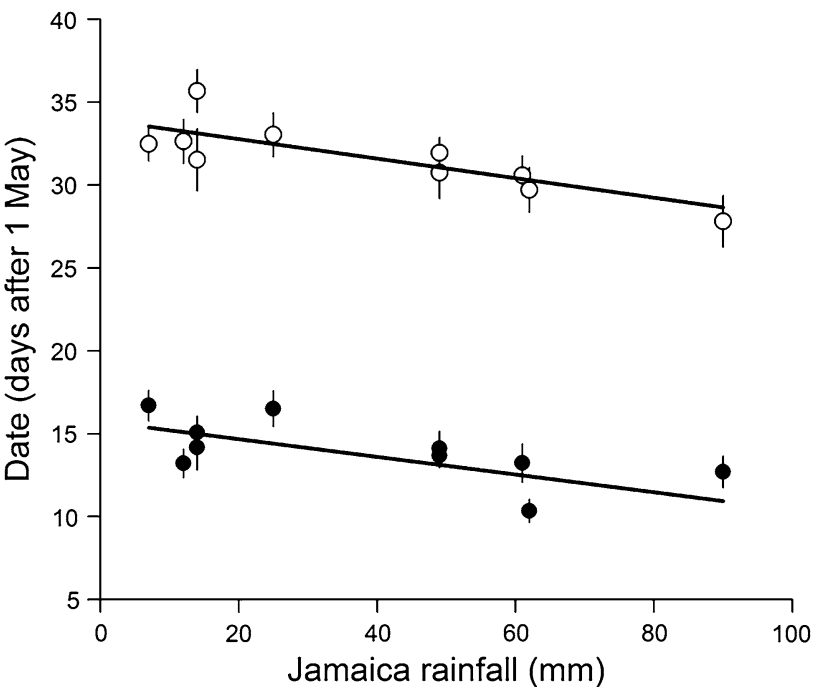

Fig. 2 Relationship between mean January to March rainfall in Jamaica and adult male American redstart arrival (filled circles; mean \pm SE) and female first egg date (empty circles; mean \pm SE) at a breeding site in Ontario. Solid lines show predicted relationship based on final models (Table 2)

relationship was marginally non-significant for females $\left(r^{2}=0.57, t_{4}=-2.29, P=0.084\right)$ (see also Studds and Marra 2011).

\section{Discussion}

The evidence for strong migratory connectivity in American redstarts led us to predict that climatic conditions experienced in eastern non-breeding areas might influence bird phenology in eastern breeding populations, whereas conditions experienced in western non-breeding areas might influence bird phenology in western breeding populations. We found support for this pattern for arrival and laying dates in two populations breeding at opposite sides of their breeding range in North America (Table 2): 


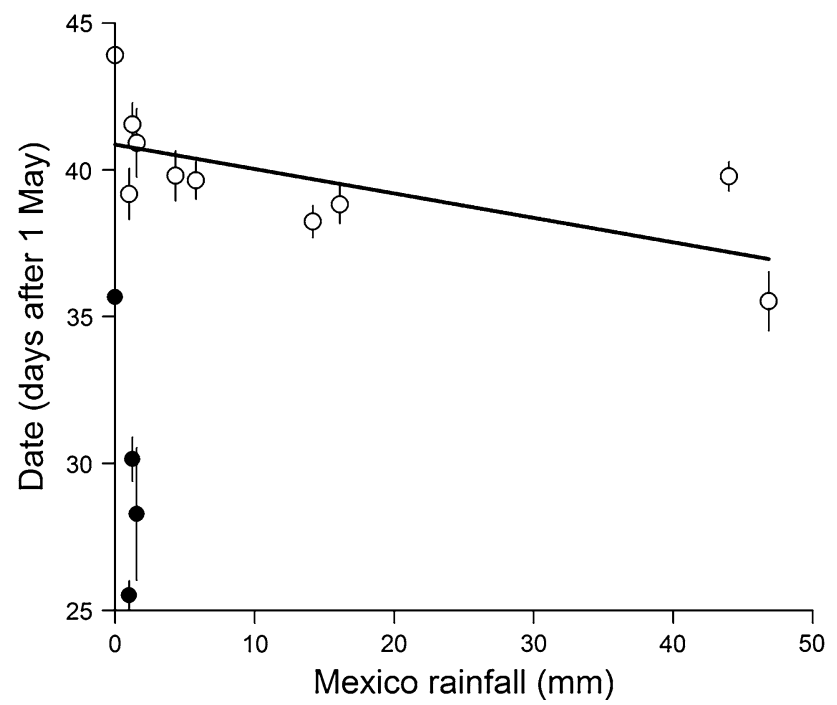

Fig. 3 Relationship between mean January to March rainfall in Mexico and adult male American redstart arrival (filled circles; mean $\pm \mathrm{SE}$ ) and female first egg date (empty circles; mean $\pm \mathrm{SE}$ ) at a breeding site in Alberta. Solid lines show predicted relationship based on final models (Table 2)

a population in Ontario experienced earlier male arrival and female first egg dates when rainfall in Jamaica was greater, whereas a population in Alberta experienced earlier female first egg dates when rainfall in eastern Mexico was greater. The relationship between rainfall and male arrival dates was not significant in Alberta, perhaps due to the small number of years in this analysis. The magnitude of these associations was similar between populations, despite overall differences in absolute rainfall between non-breeding locations ( $x$-axis on Fig. 2 vs. $x$-axis on Fig. 3), suggesting that American redstarts respond in the same way to changes in winter rainfall across their range. Finally, we found that mean population-level responses were similar to within-individual changes in arrival and laying dates of returning birds that experienced years of differing non-breeding season rainfall, indicating that the above associations could likely be explained entirely by phenotypic plasticity, at least in Ontario where sufficient data were available to perform these analyses.

In a similar study, Wilson et al. (2011) detected associations between the Normalized Difference Vegetation Index (NDVI) during the winter in the Greater Antilles and American redstart abundance in eastern breeding populations the following spring. No associations were discovered for the western non-breeding range in Mexico and western breeding populations. They concluded that migratory connectivity might be weaker in western populations or that winter conditions might not affect redstarts similarly across their range. Our results imply otherwise. Differences between studies in precise locations chosen to represent the likely non-breeding range of western breeding populations
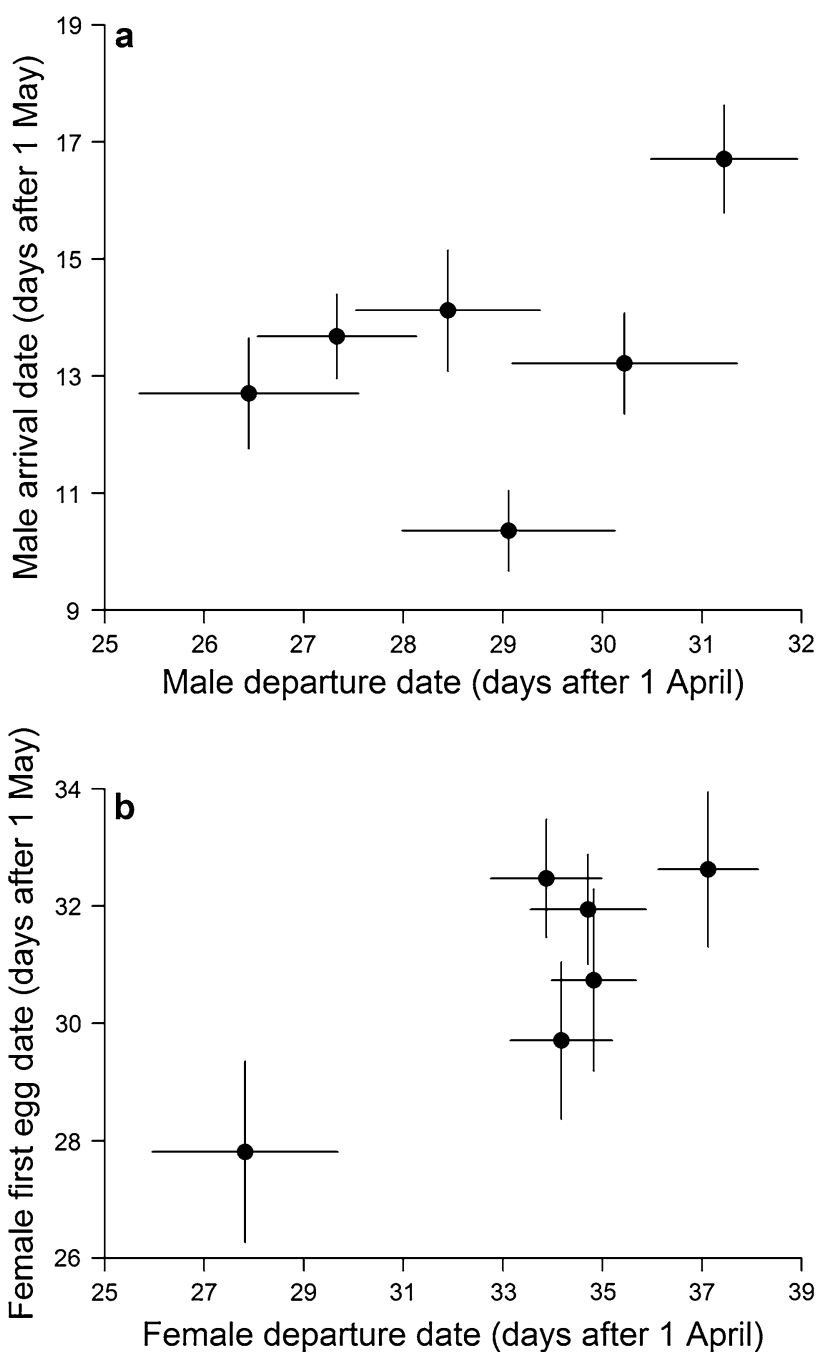

Fig. 4 Association between annual departure date from Jamaica (mean $\pm \mathrm{SE}$ ) and a arrival (mean $\pm \mathrm{SE}$ ) at a breeding site in Ontario for adult male American redstarts, and $\mathbf{b}$ first egg date (mean $\pm \mathrm{SE}$ ) at a breeding site in Ontario for female American redstarts

could account for this discrepancy. Alternatively, nonbreeding conditions could influence redstart phenology and abundance in different ways across their range (see also Balbontín et al. 2009a). In any case, this is among the first studies to document at least some spatial correspondence in response to winter conditions between different breeding populations in a long-distance migrant. Other studies include barn swallows (Hirundo rustica) breeding in Denmark and Spain that showed different arrival, dispersal, and survival responses to large-scale climate indices in winter (Balbontín et al. 2009a), and different breeding populations of pied flycatchers (Ficedula hypoleuca) that showed variation in the strength of the relationship between laying date and winter vegetation productivity (Both et al. 2006).

Interestingly, we detected no significant associations between local temperature on the breeding grounds and 
arrival or laying dates (Table 2), which indicates that the influence of winter conditions on American redstart phenology may be stronger than that of breeding conditions (see also Gordo et al. 2005), at least for the time periods that we examined. Likewise, Wilson et al. (2011) found no associations between breeding season temperature and population trends across the redstart breeding range. However, it remains possible that nearby temperature acts to fine-tune arrival and egg-laying dates once redstarts approach and reach the breeding grounds (Tøttrup et al. 2010).

Population differences in response to weather conditions on or close to the breeding grounds have been demonstrated in other species. As one example, pied flycatchers migrating later to northern Europe have experienced warming temperatures and have advanced their arrival, whereas those migrating earlier to western and central Europe have not experienced warming temperatures and have not advanced their arrival (Both and te Marvelde 2007). As another example, advances in tree swallow (Tachycineta bicolor) laying dates from different populations were found to correspond to local increases in temperature (Dunn and Winkler 1999). These types of patterns, combined with our findings in this study, suggest that spatio-temporal variation in climate change could potentially have disparate effects on different breeding populations of long-distance migrants, as is the case in short-distance migrants and residents (Sanz 2002; Visser et al. 2003; Both and te Marvelde 2007).

Despite the small number of years and thus correspondingly low power, our preliminary analyses provided some indication of positive associations between departure dates from a Jamaican non-breeding population and arrival and egg-laying dates in Ontario (Fig. 4). Such a result was expected given that winter conditions in Jamaica were related to redstart phenology in Ontario and departures from Jamaica (this study; Studds and Marra 2011). Unfortunately, we were not able to test whether the same was true for non-breeding populations in Mexico and in an Alberta breeding population, though this would be a reasonable prediction. Few studies have explicitly linked mean winter departure of populations to subsequent spring arrival dates (but see Gunnarsson et al. 2006), though a handful of studies have tracked individuals during migration. As one example, bar-tailed godwits (Limosa lapponica baueri) that departed the non-breeding grounds earlier tended to arrive to the breeding grounds earlier, with this relationship apparently mediated by breeding latitude (Conklin et al. 2010). However, no relationship between individual departure and arrival dates was found in greater snow geese (Anser caerulescens atlanticus) (Bêty et al. 2004). It may be that yearly variation in population departure dates, perhaps as a consequence of variation in winter conditions (Gunnarsson et al. 2006), can be associated with variation in arrival dates, but that this relationship is not always true for individuals within a given year.

The comparative strength of migratory connectivity in redstarts might have contributed to our findings. If a relationship between the degree of connectivity and response to climate is a general phenomenon, then the effects of continued climate change will likely be most severe in strongly connected populations. We are not aware of any studies that have related the degree of migratory connectivity to responses to climate variation, though a study of Cerulean warblers (Setophaga cerulean) found that populations with weaker connectivity did not suffer declines as severe as those with stronger connectivity (Jones et al. 2008). Future research could use evidence from stable isotopes of tissue grown on the non-breeding grounds in combination with climatic data to determine the likely nonbreeding locations of breeding individuals and their predicted phenological responses, though such comparisons may be complicated by associations between isotopic signatures and weather itself (Farmer et al. 2008). Better yet, the increasing use of telemetry and geolocators may allow for accurate identification of both non-breeding location and arrival timing.

The associations that we detected between winter conditions and redstart phenology were negative, i.e., earlier arrival and laying dates in years of greater rainfall. This pattern mirrors well-documented associations between breeding ground arrival dates and winter habitat quality inferred from stable-carbon isotopes: American redstarts overwintering in high-quality wet habitat tend to arrive earlier than those overwintering in low-quality dry habitat (Marra et al. 1998; Reudink et al. 2009; Tonra et al. 2011). Our findings are also in agreement with studies showing earlier passage and arrival in certain European long-distance migratory bird populations in years of higher precipitation and vegetation productivity on their African non-breeding grounds (Saino et al. 2004; Gordo et al. 2005; Gordo and Sanz 2008). Interestingly, some European long-distance migrants have shown opposite patterns, with delayed passage in years of increased vegetation productivity at nonbreeding or passage areas (Tøttrup et al. 2008; Robson and Barriocanal 2011). And in the case of barn swallows, the direction of this association appears to differ among populations (Møller and Merilä 2004; Balbontín et al. 2009a, b). Such variation is not yet well understood, but differences among species and populations in their general ecology and migratory timing and routes, as well as differences among studies in the metrics of migratory phenology used (e.g., passage vs. arrival, first arrival vs. mean arrival) could play a role. Furthermore, the exact non-breeding and breeding origins of populations in the above studies were often not 
known (for further discussion, see Balbonín et al. 2009b; Robson and Barriocanal 2011). In any case, we now have support that increased winter rainfall, which is correlated with increased arthropod prey abundance, influences migratory phenology in breeding and non-breeding populations of a North American long-distance migrant (Studds and Marra 2007, 2011; present study).

We found that variation in breeding ground phenology in Ontario could be largely explained by individual behaviour. Banded individuals were generally able to arrive and lay eggs earlier in years of improved winter conditions, and the magnitude of this association was very similar to that of the population as a whole. We expected that phenotypic plasticity would be able to account for associations between winter conditions and phenology in American redstarts for several reasons. First, the relatively small number of years in our dataset and the lack of a directional trend in winter rainfall over this timescale (results not shown) might negate the potential for microevolution or its detection, and high breeding site fidelity in adult redstarts might counteract the potential for dispersal (Studds et al. 2008). Second, prior work with American redstarts has demonstrated the importance of non-breeding habitat quality in influencing individual condition and departure dates (Marra et al. 1998; Marra and Holmes 2001; Studds and Marra 2011), spring arrival and reproductive success (see above), and natal dispersal (Studds et al. 2008). Thus, our results provide further evidence that individual migratory schedules in long-distance migrants are not always rigidly fixed and can vary along with climatic conditions (Saino et al. 2004; Studds and Marra 2011).

Incorporating knowledge of migratory connectivity across a species range should improve our ability to predict how different populations will respond to climate change. Here, we have shown that separate breeding populations can have similar but independent and spatially specific associations with weather conditions from non-breeding areas to which they are likely linked. In American redstarts, such responses may prove to be maladaptive due to predicted patterns of global change. Drying conditions in tropical non-breeding areas in combination with warming trends across the temperate breeding range (Neelin et al. 2006; IPCC 2007) could presumably cause population declines as a result of the tight association between early arrival and reproductive success (Lozano et al. 1996; Smith and Moore 2005; Reudink et al. 2009). Unfortunately, this may be the case for a number of long-distance migrants owing to climate change at different periods of their annual cycle (Gordo et al. 2005; Both 2010).

Acknowledgments We thank all of the field assistants who contributed to this study. C. Eckert helped with data analysis. Funding was provided by Queen's University, the Natural Sciences and
Engineering Research Council of Canada, the Canadian Foundation for Innovation, the National Science Foundation, the Smithsonian Institution, the Ontario Innovation Trust, Sigma Xi, the American Ornithologists' Union, the Society of Canadian Ornithologists, and the American Museum of Natural History. Procedures were performed in accordance with permits from the Queen's University Animal Care Committee (Ratcliffe-2010-009) and the Canadian Wildlife Services (banding permit 10771E and collection permit CA0233). All methods used in this study comply with current laws of the country in which they were performed.

\section{References}

Angelier F, Tonra CM, Holberton RL, Marra PP (2011) Short-term changes in body condition in relation to habitat and rainfall abundance in American redstarts Setophaga ruticilla during the non-breeding season. J Avian Biol 42:335-341. doi:10.1111/ j.1600-048X.2011.05369.x

Balbontín J, Møller AP, Hermosell IG, Marzal A, Reviriego M, de Lope F (2009a) Divergent patterns of impact of environmental conditions on life history traits in two populations of a longdistance migratory bird. Oecologia 159:859-872. doi:10.1007/ s00442-008-1267-8

Balbontín J, Møller AP, Hermosell IG, Marzal A, Reviriego M, de Lope F (2009b) Individual responses in spring arrival date to ecological conditions during winter and migration in a migratory bird. J Anim Ecol 78:981-989. doi:10.1111/j.1365-2656.2009. 01573.x

Bates D, Martin M, Bolker B (2011) Lme4: linear mixed-effects models using S4 classes. R package version 0.999375-42. http://CRAN.R-project.org/package=lme4

Bêty J, Giroux J-F, Gauthier G (2004) Individual variation in timing of migration: causes and reproductive consequences in greater snow geese (Anser caerulescens atlanticus). Behav Ecol Sociobiol 57:1-8. doi:10.1007/s00265-004-0840-3

Both C (2010) Flexibility of timing of avian migration to climate change masked by environmental constraints en route. Curr Biol 20:243-248. doi:10.1016/j.cub.2009.11.074

Both C, te Marvelde L (2007) Climate change and timing of avian breeding and migration throughout Europe. Clim Res 35:93-105. doi:10.3354/cr00716

Both C, Artemyev AV, Blaauw B, Cowie RJ, Dekhuijzen AJ, Eeva T, Enemar A, Gustafsson L, Ivankina EV, Järvinen A, Metcalfe NB, Nyholm NEI, Potti J, Ravussin P-A, Sanz JJ, Silverin B, Slater FM, Sokolov LV, Török J, Winkel W, Wright J, Zang H, Visser ME (2004) Large-scale geographical variation confirms that climate change causes birds to lay earlier. Proc R Soc Lond B 271:1657-1662. doi:10.1098/rspb.2004.2770

Both C, Sanz JJ, Artemyev AV, Blaauw B, Cowie RJ, Dekhuizen AJ, Enemar A, Järvinen A, Nyholm NEI, Potti J, Ravussin P-A, Silverin B, Slater FM, Sokolov LV, Visser ME, Winkel W, Wright J, Zang H (2006) Pied flycatchers Ficedula hypoleuca travelling from Africa to breed in Europe: differential effects of winter and migration conditions on breeding date. Ardea 94:511-525

Charmantier A, McCleery RH, Cole LR, Perrins C, Kruuk LEB, Sheldon BC (2008) Adaptive phenotypic plasticity in response to climate change in a wild bird population. Science 320:800-803. doi:10.1126/science.1157174

Conklin JR, Battley PF, Potter MA, Fox JW (2010) Breeding latitude drives individual schedules in a trans-hemispheric migrant bird. Nature Comm 1:67. doi:10.1038/ncomms1072

Dunn PO, Winkler DW (1999) Climate change has affected the breeding date of tree swallows throughout North America. Proc R Soc Lond B 266:2487-2490 
Farmer A, Cade BS, Torres-Dowdall J (2008) Fundamental limits to the accuracy of deuterium isotopes for identifying the spatial origin of migratory animals. Oecologia 158:183-192. doi: 10.1007/s00442-008-1143-6

Ficken MS (1963) Courtship of the American Redstart. Auk 80:307-317

Gienapp P, Teplitsky C, Alho JS, Mills JA, Merilä J (2008) Climate change and evolution: disentangling environmental and genetic responses. Mol Ecol 17:167-178. doi:10.1111/j.1365-294X.2007. 03413.x

Glantz SA, Slinker BK (2001) Primer of applied regression and analysis of variance, 2nd edn. McGraw-Hill, New York

Gordo O, Sanz JJ (2008) The relative importance of conditions in wintering and passage areas on spring arrival dates: the case of long-distance Iberian migrants. J Ornithol 149:199-201. doi: 10.1007/s10336-007-0260-z

Gordo O, Brotons L, Ferrer X, Comas P (2005) Do changes in climate patterns in wintering areas affect the timing of the spring arrival of trans-Saharan migrant birds? Glob Change Biol 11:12-21. doi:10.1111/j.1365-2486.2004.00875.x

Gunnarsson TG, Gill JA, Atkinson PW, Gélinaud G, Potts PM, Croger RE, Gudmundsson GA, Appleton GE, Sutherland WJ (2006) Population-scale drivers of individual arrival times in migratory birds. J Anim Ecol 75:1119-1127. doi:10.1111/j.13652656.2006.01131.x

Hitch AT, Leberg PL (2007) Breeding distributions of North American bird species moving north as a result of climate change. Conserv Biol 21:534-539. doi:10.1111/j.1523-1739. 2006.00609.x

IPCC (2007) Climate change 2007: the physical basis. Contributions of Working Group I to the fourth assessment of the Intergovernmental Panel on Climate Change. IPCC Secretariat, Geneva, Switzerland

Jones J, Norris DR, Girvan MK, Barg JJ, Kyser TK, Robertson RJ (2008) Migratory connectivity and rate of population decline in a vulnerable songbird. Condor 110:538-544. doi:10.1525/cond. 2008.8563

Lehikoinen E, Sparks TH (2010) Changes in migration. In: Møller AP, Fiedler W, Berthold P (eds) Effects of climate change on birds. Oxford University Press, Oxford, pp 89-112

Lozano GA, Perreault S, Lemon RE (1996) Age, arrival date and reproductive success of male American Redstarts Setophaga ruticilla. J Avian Biol 27:164-170

Marra PP, Holmes RT (2001) Consequences of dominance-mediated habitat segregation in American redstarts during the nonbreeding season. Auk 118:92-104. doi:10.1642/0004-8038(2001)118[0092: CODMHS]2.0.CO;2

Marra PP, Hobson KA, Holmes RT (1998) Linking winter and summer events in a migratory bird by using stable-carbon isotopes. Science 282:1884-1886. doi:10.1126/science.282.5395.1884

Marra PP, Francis CM, Mulvihill RS, Moore FR (2005) The influence of climate on the timing and rate of spring bird migration. Oecologia 142:307-315. doi:10.1007/s00442-004-1725-x

Marra PP, Studds CE, Webster M (2010) Migratory connectivity. In: Breed MD, Moore J (eds) Encyclopedia of animal behavior. Academic, Oxford, pp 455-461

Matthysen E, Adriaensen F, Dhondt AA (2011) Multiple responses to increasing spring temperatures in the breeding cycle of blue and great tits (Cyanistes caeruleus, Parus major). Glob Change Biol 17:1-16. doi:10.1111/j.1365-2486.2010.02213.x

Møller AP (1994) Phenotype-dependent arrival time and its consequences in a migratory bird. Behav Ecol Sociobiol 35:115-122. doi:10.1007/BF00171501

Møller AP, Merilä J (2004) Analysis and interpretation of long-term studies investigating responses to climate change. Adv Ecol Res 35:111-130. doi:10.1016/S0065-2504(04)35006-3
Møller AP, Szép T (2005) Rapid evolutionary change in a secondary sexual character linked to climate change. J Evol Biol 18:481495. doi:10.1111/j.1420-9101.2004.00807.x

Neelin JD, Münnich M, Su H, Meyerson JE, Holloway CE (2006) Tropical drying trends in global warming models and observations. Proc Natl Acad Sci USA 103:6110-6115. doi:10.1073/ pnas.0601798103

Norris DR, Marra PP, Bowen GJ, Ratcliffe LM, Royle JA, Kyser TK (2006) Migratory connectivity of a widely distributed songbird, the American redstart (Setophaga ruticilla). Ornithol Monogr 2006:14-28

Pyle P (1997) Identification guide to North American birds. Part 1. Slate Creek Press, Bolinas

R Development Core Team (2011) R: A language and environment for statistical computing. R Foundation for Statistical Computing, Vienna, Austria. http://www.R-project.org/

Reudink MW, Marra PP, Kyser TK, Boag PT, Langin KM, Ratcliffe LM (2009) Non-breeding season events influence sexual selection in a long-distance migratory bird. Proc R Soc Lond B 276:1619-1626. doi:10.1098/rspb.2008.1452

Robson D, Barriocanal C (2011) Ecological conditions in wintering and passage areas as determinants of timing of spring migration in trans-Saharan migratory birds. J Anim Ecol 80:320-331. doi: 10.1111/j.1365-2656.2010.01772.x

Root TL, Price JT, Hall KR, Schneider SH, Rosenzweig C, Pounds JA (2003) Fingerprints of global warming on wild animals and plants. Nature 421:57-60. doi:10.1038/nature01333

Saino N, Szép T, Romano M, Rubolini D, Spina F, Møller AP (2004) Ecological conditions during winter predict arrival date at the breeding quarters in a trans-Saharan migratory bird. Ecol Lett 7:21-25. doi:10.1046/j.1461-0248.2003.00553.x

Saino N, Rubolini D, Jonzén N, Ergon T, Montemaggiori A, Stenseth NC, Spina F (2007) Temperature and rainfall anomalies in Africa predict timing of spring migration in trans-Saharan migratory birds. Clim Res 35:123-134. doi:10.3354/cr00719

Sanz JJ (2002) Climate change and breeding parameters of great and blue tits throughout the western Palaearctic. Glob Change Biol 8:409-422. doi:10.1046/j.1365-2486.2002.00496.x

Sherry TW, Holmes RT (1997) American Redstart (Setophaga ruticilla). In: Pool A (ed) The birds of North America Online. Cornell Lab of Ornithology, Ithaca. http://bna.birds.cornell. edu/bna/

Smith RJ, Moore FR (2005) Arrival timing and seasonal reproductive performance in a long-distance migratory landbird. Behav Ecol Sociobiol 57:231-239. doi:10.1007/s00265-004-0855-9

Smith RJ, Mabey SE, Moore FR (2009) Spring passage and arrival patterns of American redstarts in Michigan's eastern upper peninsula. Wilson J Ornithol 121:290-297. doi:10.1676/08-051.1

Studds CE, Marra PP (2007) Linking fluctuations in rainfall to nonbreeding season performance in a long-distance migratory bird, Setophaga ruticilla. Clim Res 35:115-122. doi:10.3354/ cr00718

Studds CE, Marra PP (2011) Rainfall induced changes in food availability modify the spring departure program of a migratory bird. Proc R Soc Lond B 278:3437-3443. doi:10.1098/rspb. 2011.0332

Studds CE, Kyser TK, Marra PP (2008) Natal dispersal driven by environmental conditions interacting across the annual cycle of a migratory songbird. Proc Natl Acad Sci USA 105:2929-2933. doi:10.1073/pnas.0710732105

Thomas CD, Lennon JL (1999) Birds extend their ranges northwards. Nature 399:213. doi:10.1038/20335

Tonra CM, Marra PP, Holberton RL (2011) Migration phenology and winter habitat quality are related to circulating androgen in a long-distance migratory bird. J Avian Biol 42:397-404. doi: 10.1111/j.1600-048X.2011.05333.x 
Tøttrup AP, Thorup K, Rainio K, Yosef R, Lehikoinen E, Rahbek C (2008) Avian migrants adjust migration in response to environmental conditions en route. Biol Lett 4:685-688. doi:10.1098/ rsbl.2008.0290

Tøttrup AP, Rainio K, Coppack T, Lehikoinen E, Rahbek C, Thorup $\mathrm{K}$ (2010) Local temperature fine-tunes the timing of spring migration in birds. Integr Comp Biol 50:293-304. doi:10.1093/ $\mathrm{icb} / \mathrm{icq} 028$

Visser ME, Adriaensen R, van Balen JH, Blondel J, Dhondt AA, van Dongen S, du Feu C, Ivankina EV, Kerimov AB, de Laet J, Matthysen E, McCleery R, Orell M, Thomson DL (2003)
Variable responses to large-scale climate change in European Parus populations. Proc R Soc Lond B 270:367-372. doi: 10.1098/rspb.2002.2244

Wilson S, LaDeau SL, Tøttrup AP, Marra PP (2011) Range-wide effects of breeding- and nonbreeding season climate on the abundance of a Neotropical migrant songbird. Ecology 92: 1789-1798. doi:10.1890/10-1757.1

Zuur AF, Ieno EN, Walker NJ, Saveliev AA, Smith GM (2009) Mixed effects models and extensions in ecology with $\mathrm{R}$. Springer, New York 